\title{
Water deficit effect on the accumulation of biomass and artemisinin in annual wormwood (Artemisia annua L., Asteraceae)
}

\author{
José A. Marchese ${ }^{1 *}$, Jorge F.S. Ferreira ${ }^{2}$, Vera L.G. Rehder ${ }^{3}$ and 0 smar Rodrigues $^{4}$ \\ ${ }^{1}$ Laboratory of Biochemistry and Plant Physiology, Federal University of Technology - Paraná (UTFPR), Pato \\ Branco-PR, 85503-390, Brazil. \\ ${ }^{2}$ Appalachian Farming Systems Research Center (USDA-ARS), 1224 Airport Rd., Beaver, WV 25813, United States. \\ ${ }^{3}$ Chemical, Biological and Agricultural Pluridisciplinary Research Center, Campinas State University, Paulíinia-SP, \\ 13140-000, Brazil. \\ ${ }^{4}$ Laboratory of Plant Physiology, Brazilian Agricultural Research Corporation (EMBRAPA-CNPT), Passo Fundo-RS, \\ CEP 99001-970, Brazil.
}

*Corresponding author: abramo@pq.cnpq.br, fax: +55 46 3220-2548.

Received: 23 November 2009; Accepted: 05 April 2010.

\begin{abstract}
Despite the importance of Artemisia annua L. as the only source of the anti-parasitic drug artemisinin, little is known on the effects of biotic and abiotic stress on artemisinin accumulation. Water deficit is the most limiting factor on plant growth, however it can trigger secondary metabolite accumulation, depending on the plant growth stage and intensity. $A$. annua cultivated in growth chambers was submitted to five water deficit treatments (watered, 14, 38, 62 e 86 hours without irrigation). Water deficits of 38 and 62 hours ( $\Psi \mathrm{w}=-1.39$ and $-2.51 \mathrm{MPa}$, respectively) increased leaf artemisinin content, but only 38 hours led to a significant increase in both leaf and plant artemisinin (29\%), with no detriment to plant biomass production. The other treatments had no effect on, or decreased artemisinin accumulation. A. annua plants tolerated well water deficit treatments, including the most severe water deficit applied ( $\Psi \mathrm{w}-3.97 \mathrm{MPa}$ or 86 hs without irrigation) and recovered their turgor pressure after rehydration. These results suggest that moderate water deficit prior to harvesting the crop may not only reduce time and costs in drying the crop, but can also induce artemisinin accumulation, both of which increase crop profit margins. Results also suggest that artemisinin could be part of $A$. annua chemical system of defense against water deficit.
\end{abstract}

Key words: Malaria; secondary metabolism; terpene; drought; water stress.

\section{RESUMO}

A despeito da importância da Artemisia annua L. como a única fonte da droga anti-parasitária artemisinina, muito pouco é sabido sobre o papel dessa molécula em plantas sob estresses biótico e abiótico. A deficiência hídrica é o principal fator limitante no crescimento vegetal, mas pode induzir a acumulação de metabólitos secundários, dependendo da intensidade e fase de desenvolvimento da planta. Plantas de $A$. annua cultivadas em câmaras de crescimento foram submetidas a cinco tratamentos (plantas irrigadas e com 14, 38, 62 e 86 horas sem irrigação). Deficiências hídricas de 38 e 62 horas ( $\Psi w=-1.39$ e -2.51 $\mathrm{MPa}$, respectivamente) aumentaram o conteúdo foliar de artemisinina, mas somente a deficiência hídrica de 38 horas induziu um 
aumento significativo da molécula em folhas (29\%) e planta inteira, sem afetar o acúmulo de biomassa. Os outros tratamentos não afetaram significativamente o conteúdo de artemisinina. As plantas de $A$. annua apresentaram uma boa tolerância a deficiência hídrica, incluindo o tratamento mais severo ( $\Psi$ w $-3.97 \mathrm{MPa}$ ou $86 \mathrm{~h}$ sem irrigação) e recuperaram a pressão de turgor após a reidratação. Estes resultados sugerem que uma deficiência hídrica moderada imediatamente antes da colheita de $A$. annua pode não somente reduzir o tempo e os custos de secagem da cultura, mas também induzir ao acúmulo de artemisinina, condições que, conjuntamente, são benéficas para o cultivo commercial da espécie. Finalmente, estes resultados sugerem que a artemisinina pode ser parte do sistema químico de defesa da $A$. annua contra a deficiência hídrica.

Palavras-chave: Malária; metabolismo secundário; terpenos; estiagem, estresse hídrico.

Abbreviations: DAS, days after sowing; PAR, photosynthetic active radiation; WD, water deficit; $\Psi$ w, water potential.

\section{INTRODUCTION}

Plants have evolved while constantly adapting to environmental stresses. They have adapted through their morphology, physiology, and biochemistry. Recently, there has been an increased interest in understanding the mechanisms of adaptation of plants to their adverse ecosystems. These adaptations may include both primary and secondary metabolism (Dey and Harborne, 1997). Plants have evolved a wide range of secondary metabolites that deter herbivores, pathogens, competing species, attract pollinators, and protect them from abiotic stress such as water deficit (Harborne, 1993; Baldwin et al., 2001; Oostendorp et al., 2001; Heath and Boller, 2002; Wittstock and Ghershenzon, 2002; Danner et al., 2008).

Some secondary metabolites are now seen as desirable commodities, and no longer as "waste compounds" (Briskin, 2000; Laird and Kate, 2002). Recent advances in the understanding of secondary metabolism in plants resulted from the attempt to increase the production of their bioactive compounds desired for their medicinal, aromatic, and culinary uses (Marchese et al., 2009). Advances in understanding the influences of the environment in the regulation of such compounds may lead to their advantageous manipulation in plants (Ghershenzon, 1984).

The stresses proved to alter the secondary metabolite accumulation include water deficit, UV irradiation, nutritional deficiency, salinity, heavy metals, temperature extremes, insect and pathogen attacks, and mechanical damage (Ghershenzon, 1984; Mann, 1987; Harborne, 1993; Dixon and Paiva, 1995; Dey and Harborne, 1997; Danner et al., 2008).
When conditions and resources are favorable, the priority is growth and development, decreasing the availability of carbon to support secondary metabolism. When conditions and resources for growth and development are scarce, photosynthesis and growth are affected, but carbon at low levels can still be directed to support vital plant functions (Herms and Mattson, 1992; Kramer and Boyer, 1995; Larcher, 2003), leading to a decrease in the production of secondary metabolites (Herms and Mattson, 1992; Marchese and Figueira, 2005).

At moderate stresses, there is a limit on the translocation of carbon to its sinks, with the remaining carbon accumulating as carbohydrates. Thus, factors that limit growth more than photosynthesis, such as moderate water-deficit, low temperatures, and moderate nutrient deficiency can actually increase the carbon pool allocated to secondary metabolism, with little or no competition with growth and development (Herms and Mattson, 1992; Harborne, 1993; Marchese and Figueira, 2005). Consequently, quantitative variations on secondary metabolism are directly linked to variations on the plant growth rate (Herms and Mattson, 1992; Marchese and Figueira, 2005).

Terpenes are a group of compounds thatare extraordinarily diverse in terms of chemistry, structure, and function. Despite the fact that the terpenes biosynthetic pathway has been characterized in some detail at the molecular level over the last two decades, its regulation during plant responses to drought stress is still poorly understood (Rodríguez-Concepción and Boronat, 2002; Liu et al., 2005). According to Franz (1983), Palevitch (1987) and Marchese and Figueira (2005) one of the most important factors affecting secondary metabolism is water availability. Usually, limited availability of water has a 
negative effect on plant growth and development. However, a moderate water deficit has sometimes proved beneficial for the accumulation of biologically-active compounds in medicinal and aromatic plants (Ghershenzon, 1984; Palevitch, 1987). According to Ghershenzon (1984), in herbaceous plants and shrubs, terpenes tend to increase under stress, mainly under moderate water deficit.

The leaves of Artemisia annua (L.) are a rich source of artemisinin, a sesquiterpene lactone used as the raw material for the production of semi-synthetic derivatives that are more stable, bioavailable, and effective against chloroquine-resistant strains of Plasmodium falciparum (Klayman, 1985; Luo and Shen, 1987; Balint, 2001; Marchese and Rehder, 2001; Enserink, 2005; WHO 2005, Marchese et al., 2005). Besides its antimalarial activity, artemisinin has proved effective against cancer (Posner et al., 1999; Singh and Lai, 2004; Efferth, 2005), Eimeria spp., Babesia spp., Leishmania spp., Neospora caninum, Trypanosoma brucei rhodesiense (Mishina et al., 2007), and Schistosoma spp. (Utzinger et al., 2001; Xiao et al., 2004), the latter living in the circulatory system of the host. Also, ethanolic extract of aerial parts of $A$. annua and artemisinin exhibited effect against Epilachna paenulata and Spodoptera eridania (Maggi et al., 2005). A. annua oils are used in the perfume and cosmetic industry (Galambosi, 1980; Jain et al., 1996). Finally, A. annua also exhibited allelopathic effect on the germination and initial development of lettuce and wild poinsettia seedlings (Magiero et al., 2009).

Artemisinin production in $A$. annua is affected mainly by its genetic potential, but also by environmental conditions to which the plants are subjected to (Singh et al., 1986; Chen and Zhang, 1987; Ferreira et al., 1995b; Marchese and Rehder, 2001, Marchese et al., 2002), such as a moderate potassium deficiency (Ferreira, 2007).

Our main objective was to evaluate the effect of water deficit on biomass and artemisinin accumulation in $A$. annua.

\section{MATERIAL AND METHODS}

The experiment was conducted in growth chambers (model CMP 4030 - Conviron, Manitoba, Canada) at the National Wheat Research Center (CNPT/EMBRAPA) in Passo Fundo, RS, Brazil (28015' S, 52024' W e $689 \mathrm{~m}$ above sea level). We utilized seeds of the $A$. annua hybrid $2 / 39 \times 1 \mathrm{~V}$, developed by the breeding program conducted by CPQBA/ UNICAMP (Campinas, São Paulo, Brazil).

Experimental Design and Statistical Analysis: The experiment was set in a complete randomized design with five treatments: four levels of water deficit - WD, plus the irrigated control (control plants paired to each WD treatments) and six replicates per treatment. Each replicate was constituted of a single plant. The four WD treatments were $14,38,62$, and $86 \mathrm{hr}$ of drought after the last irrigation. The treatment averages were compared with control by the Student t-test using SYSTAT 5.0 (Systat Software Inc. - San Jose, California, USA).

Growth Condition: Plants were grown in a uniform mixture of soil with high levels of organic matter and a dystrophic latosol with a $\mathrm{pH}=6.8$, organic matter of $25.5 \mathrm{mg} / \mathrm{kg}$, and the following nutrient concentration (in $\mathrm{mg} / \mathrm{kg}$ ): $\mathrm{Al}^{3+} 0.0 ; \mathrm{Ca}^{2+}$ 1,480; $\mathrm{Mg}^{2+}$ 718.8; P 65,9; $\mathrm{K}^{+}$183.3; S 2,217.6; Cu 4.8; Zn 5.2; and Fe 140.

Seeds were sown directly in plastic pots $(700-\mathrm{ml}$ capacity) containing $630 \mathrm{~g}$ of the substrate mixture described above. Each pot received approximately 10 seeds. The pots were maintained in a greenhouse set at $\pm 25^{\circ} \mathrm{C}$, and placed inside aluminum trays to allow a water film 2-cm deep to saturate the substrate pores through capillary action.

Plants were transferred 36 days after sowing (DAS) to growth chambers under the following conditions: temperature set between 21 e $24{ }^{\circ} \mathrm{C}$, relative humidity of approximately $70 \%$, and PAR (photosynthetic active radiation) of 220 $\mu \mathrm{mol} \mathrm{m} \mathrm{m}^{-2} \mathrm{~s}^{-1}$. Plants received 10.5 hours of light per day to induce flowering after the juvenile stage, which simulates the physiological stage found at harvest.

At 67 DAS, plants were randomly divided and allocated into two growth chambers. One contained the control plants (irrigated frequently) and the other contained plants that were submitted to water deficit. Each chamber contained 104 uniformly sized plants. The only parameter that changed in the growth chambers was the PAR $\left(350 \mu \mathrm{mol} \mathrm{m}^{-2} \mathrm{~s}^{-1}\right)$.

Xilem Water Potential ( $\Psi w)$ and Biomass Measurement: When plants in all treatments were at the B developmental stage (elongated internodes) described by (Delabays, 1997), at 84 DAS and with an average height of $37.3 \mathrm{~cm}$, irrigation was suspended and plants were submitted to WD treatments. 
After $14,38,62$, and 86 hours without irrigation, the plant water potential $(\Psi w)$ was measured in the xylem. Plants that survived the treatment of 86 hours of WD were rehydrated and transferred to the greenhouse (set at a maximal temperature of $31^{\circ} \mathrm{C}$ and a minimal temperature of $11^{\circ} \mathrm{C}$ ) and had their $\Psi \mathrm{w}$ measured after the 3rd and 14th days after rehydration. The $\Psi w$ was determined from the leaves at the middle section of the plants at 6:00 AM using a pressure chamber (Model 3005, Soilmoisture Equipment Corporation, Sta. Barbara, CA, USA) according to the methods described by Turner (1981) and Boyer (1995).

Besides the $\Psi \mathrm{w}$, we also recorded the dry biomass of leaves and stems, and the leaf-to-stem ratio. After the $\Psi w$ was recorded, plants were cut close to the soil surface and dried in a forced-air oven at $34{ }^{\circ} \mathrm{C} \pm 1{ }^{\circ} \mathrm{C}$ for 96 hours.

Artemisinin Analysis: Artemisinin was analyzed by HPLC-UV after derivatization to Q260. The original method, used to quantify artemisinin in rat plasma (Zhao and Zeng 1986) was modified for plant extracts (Delabays, 1997) and ratified by Marchese et al. (2001) as follows: $100 \mathrm{mg}$ of leaves dried in a forced-air oven ( $34{ }^{\circ} \mathrm{C}$ for $48 \mathrm{~h}$ ) were extracted in $5.0 \mathrm{~mL}$ of a solution containing acetonitrile and acetophenone (4.5:0.5, respectively), using an overhead stirrer (Polytron homogenizer PT300, Brinkmann Instruments Inc., Westbury, NY) for $30 \mathrm{sec}$ at 20,000 rpm, followed by six minutes at $3,200 \mathrm{rpm}$. After extraction, each $1.0 \mathrm{~mL}$ aliquot was added of $1.0 \mathrm{~mL}$ of EtOH $95 \%$ and $4.0 \mathrm{~m}$ of an aqueous solution of $\mathrm{NaOH}(0.2 \%)$. The tubes were sealed with PTFE lids and the mixture was heated to $40{ }^{\circ} \mathrm{C}$ for 15 minutes, with magnetic stirring. The solution was then quickly cooled in an ice bath while being neutralized by the addition of $4.0 \mathrm{~mL}$ of acetic acid at $0.1 \mathrm{M}$. A calibration curve for artemisinin was established with standards dissolved in $95 \% \mathrm{EtOH}$, at the concentrations of $0.04,0.2,0.5$, and $1.0 \mathrm{mg}$ of artemisinin $\mathrm{mL}^{-1}$ of EtOH 95\%. After this derivatization reaction, Q260 was detected by high-performance liquid chromatography using a Waters (model M45, Waters Corporation, Milford, MA) coupled to a UV detector (model 481 - Waters Corporation, Milford, MA), using a Waters/Novapak ${ }^{\circledR}$ reverse phase C18 $(3.9 \times 150 \mathrm{~mm}$ $x 4.0 \mu \mathrm{m}$ pore size) maintained at $47^{\circ} \mathrm{C}$. The mobile phase was isocratic, and composed of phosphate buffer (10.0 $\mathrm{mM}$ ) mixed with acetonitrile (80:20) with a flow rate of 1.0 $\mathrm{mL} \mathrm{min}{ }^{-1}$. The retention time for Q260 was 3.0 min and was $8.5 \mathrm{~min}$ for acetophenone (internal standard). Detection was performed at $260 \mathrm{~nm}$. Sample volumes of $20 \mu \mathrm{L}$ were injected manually. This method was linear in the range tested and had a high linear regression coefficient of $R^{2}=0.9998$ between concentrations and peak areas.

\section{RESULTS}

After 14, 38, 62, and 86 hours of water deficit (WD), the leaf water potential $(\Psi w)$ measured in the xylem of the stressed plants were, respectively, $-0.54 \mathrm{MPa},-1.39 \mathrm{MPa}$, $-2.51 \mathrm{MPa}$ and $-3.97 \mathrm{MPa}$ (Figure $1 A$ ).

Only the treatment of 38 hours of WD, considered moderate, resulted in a significant increase in the leaf artemisinin content (Figure 1B). The treatment under 14 hours without irrigation, with no noticed WD (Figure $1 A$ ), and the treatments with more intense WD of 62 and 86 hours were statistically similar to the control in artemisinin content (Figure $1 B)$. The treatments of 38-hr WD ( $\Psi \mathrm{w}-1.39 \mathrm{MPa})$ and 62hr WD ( $\Psi$ w $-2.51 \mathrm{MPa}$ ) presented, respectively, 29\% and $13.3 \%$ more artemisinin than the irrigated control, while the treatments 14-h WD ( $\Psi$ w $-0.54 \mathrm{MPa})$ and 86-hr WD ( $\Psi$ w $-3.97 \mathrm{MPa}$ ) presented, respectively, $6 \%$ and $11.7 \%$ less artemisinin than the watered control plants (Figure 2).

The treatment of 38-hr WD induced the highest foliar biomass accumulation and artemisinin content per plant, on a dry weight basis, compared to the control (Figure $1 C-D$ ). We also recorded the dry biomass of stems and the leaf-to-stem ratio (Table 1). No significant differences were found for most treatments for dry stem biomass or for leaf-to-stem ratio. However, the 38-h WD treatment had a dry stem biomass higher than the control. 

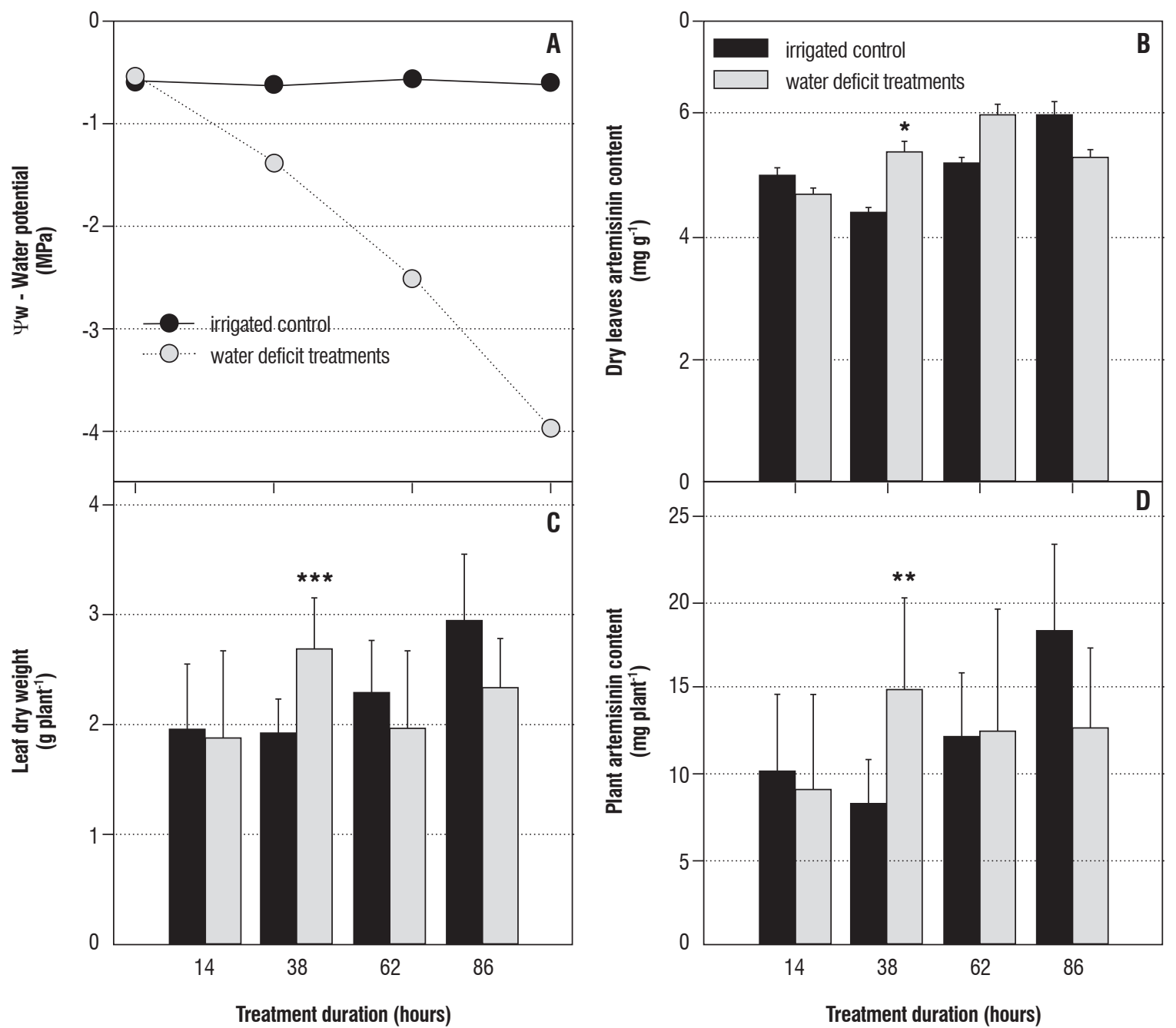

Figure 1. Effect of different levels of water deficit (hours without irrigation) on the leaf water potential - $\Psi w(A)$, dry leaves artemisinin content $(B)$, leaf dry weight $(C)$ and plant artemisinin content $(D)$ in $A$. annua plants of 84-day old cultivated in growth chambers. The irrigation was stopped 84 days after sowing to the treatments with water deficit. Means $\pm \mathrm{SE}, \mathrm{n}=6$, values significantly different at Student $t$ test. * $(p=0.084)$, ${ }^{* \star}(p=0.007)$ and ${ }^{* *}(p=0.023)$.

Plants submitted to an 86-hr WD ( $\Psi$ w $-3.97 \mathrm{MPa}$ ) slowly recovered their turgor pressure ( $\Psi \mathrm{w}-1.8 \mathrm{MPa}) 64$ hours after they were rehydrated. Fourteen days after the plants were rehydrated, we noticed the death of the apical meristem of the main stem, resulting on the expanded growth of lateral stems due to the loss of apical dominance, but the plants survived. 


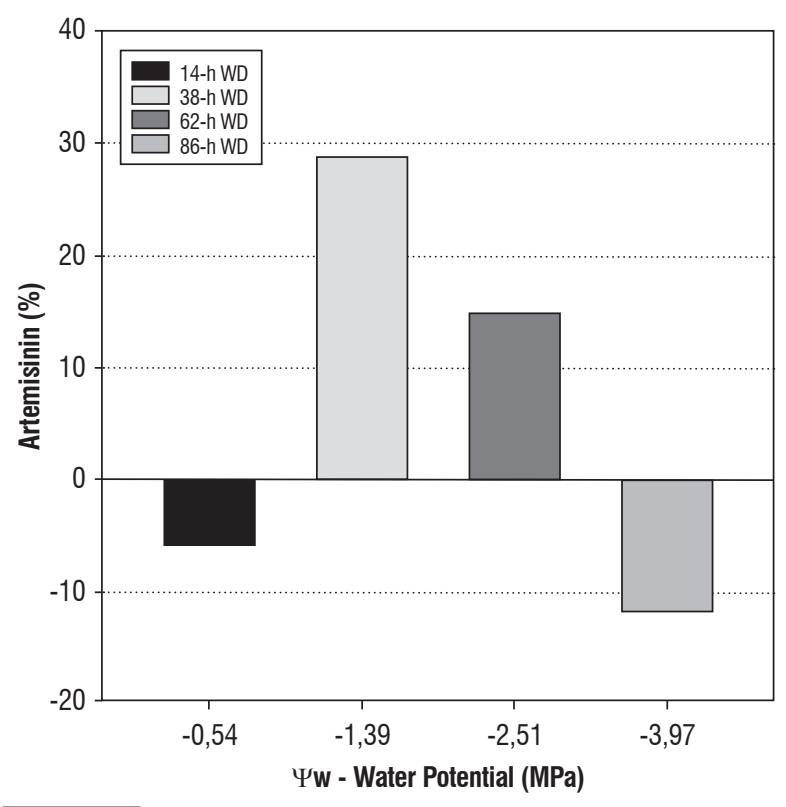

Figure 2. Variation in artemisinin concentration in 84-day old $A$. annua plants grown in growth chambers and submitted to treatments with water deficit when compared to the irrigated control (represented by concentration "0" on the $Y$ axis).

Table 1. Effect of different levels of water deficit (hours without irrigation) on the dry stem biomass accumulation and on the leaf-to-stem ratio in 84-day old $A$. annua plants grown in growth chambers.

\begin{tabular}{cccc}
\hline $\begin{array}{c}\text { Hours after } \\
\text { irrigation } \\
\text { stopped }^{\mathrm{a}}\end{array}$ & $\begin{array}{c}\text { Leaf water } \\
\text { potential } \\
-\Psi \text { w }[\mathrm{MPa}]\end{array}$ & $\begin{array}{c}\text { Dry stem biomass } \\
\text { [g plant-1 }^{\mathrm{b}}\end{array}$ & $\begin{array}{c}\text { Leaf-to-stem } \\
\text { ratio }^{\mathrm{b}}\end{array}$ \\
\hline- & $-0.59 \pm 0.10 \mathrm{c}$ & $1.37 \pm 0.90$ & $1.69 \pm 0.50$ \\
14 & $-0.54 \pm 0.08$ & $1.27 \pm 0.82$ & $1.68 \pm 0.47$ \\
\hdashline- & $-0.62 \pm 0.07 \mathrm{c}$ & $1.07 \pm 0.41$ & $1.93 \pm 0.45$ \\
38 & $-1.39 \pm 0.57$ & $1.83 \pm 0.55^{\star *}$ & $1.54 \pm 0.28$ \\
\hdashline- & $-0.57 \pm 0.12 \mathrm{c}$ & $1.50 \pm 0.57$ & $1.66 \pm 0.43$ \\
62 & $-2.51 \pm 0.81$ & $1.34 \pm 0.69$ & $1.64 \pm 0.63$ \\
\hdashline- & $-0.61 \pm 0.06 \mathrm{c}$ & $2.02 \pm 0.99$ & $1.62 \pm 0.45$ \\
86 & $-3.97 \pm 0.05$ & $1.37 \pm 0.30$ & $1.74 \pm 0.24$ \\
\hline
\end{tabular}

a Irrigation was suspended 84 days after sowing; ${ }^{b}$ Average + SD of 6 replicates; ${ }^{c}$ Irrigated control; ${ }^{* *}$ Significant $(p \leq 0.022)$ by the Student t test

\section{DISCUSSION}

To date, very little has been published about artemisinin accumulation in $A$. annua triggered by stress. To our knowledge, artemisinin responded to lead and salt-induced oxidative stress by increasing or decreasing according to the doses of the stressors in the soil (Qureshi et al., 2005) or planting in soil with high salinity (Qian et al., 2007); increased in response to a frost (Wallaart et al., 2000); and significantly increased in response to a mild potassium deficiency (Ferreira, 2007). These authors attributed artemisinin accumulation to the generation of active oxygen species in the plant in response to stress, based on the report that high levels of peroxide can be formed in plants under stress triggered by limited water, high UV-B levels, chilling conditions or tissue damage caused by pathogens or frost (Knox and Dodge, 1985).

In our study, a moderate 38-hour water deficiency (WD) was the only treatment to result in significant increase in artemisinin content (29\%), which agrees with Ghershenzon (1984) and with Herms and Mattson (1992), who reported that terpenes tend to accumulate under moderate WD. Staudt and Chuine (2005) studying the effects of an experimental increase in temperature and water deficit on terpenes emissions found Artemisia spp. plants to emit significantly more mono and sesquiterpenes under those experimental conditions. However, Hansen and Seufert (1999) and Duhl et al. (2007) reported that while a severe drought reduced the emissions of sesquiterpenes, emissions were unaffected by a mild drought.

Regarding artemisinin, Charles et al. (1993) found no significant correlation between artemisinin concentration and the WD applied for two weeks before harvest, although there was a trend for artemisinin concentration to decrease with increased negative water potential. However, one has to consider that plants under stress accumulate secondary metabolites very quickly (Kuc, 1995) and that prolonged stress could lead to a reduction in both artemisinin content and in biomass accumulation, rather than to an increase in artemisinin. In addition, Charles et al. (1993) measured $\Psi$ W in the soil and not in the plants. According to Boyer (1995), in water deficit experiments the $\Psi w$ should be measured from the plants and not from the soil, eliminating errors caused by environmental changes that would affect the $\Psi w$.

The significant increase in the leaf artemisinin content resulting from the treatment with moderate water deficit (38-hr WD) can be attributed to the fact that growth decreases under moderate WD, while photosynthesis is still ocurring. Thus, the excess photoassimilates, used in small quantity for growth, would be redirected towards secondary metabolism (Herms and Mattson, 1992; Marchese and Figueira, 2005), such as artemisinin biosynthesis. Similar results were found by Munné-Bosch et al. (2008) studying a drought-resistant shrub, Cistus creticus. Drought-induced changes in gene expression were observed at early stages of drought and were strongly correlated with levels of the corresponding metabolites, 
with simultaneous increases in some terpenes. Drought led to reductions in the relative leaf water content by $25 \%$, but did not alter the maximum efficiency of PSII, indicating the absence of damage to the photosynthetic apparatus.

Regarding the role of artemisinin in $A$. annua, previous works with hairy root cultures report the increase of artemisinin content in plants under biotic stress induced by fungal elicitors (Liu et al., 1999; Wang at al., 2002; Putalun et al., 2007; Baldi and Dixit, 2008) and abiotic stress (Qian et al., 2007; Yin et al., 2008). Ferreira (2007) used cloned Artemis ${ }^{\circledR}$ plants and found that the stress provided by potassium deficiency resulted in a $75 \%$ increase in artemisinin concentration and a $21 \%$ increase in artemisinin yield. These reports, associated with our result indicate that moderate WD can increase significantly the leaf artemisinin content, supporting the hypothesis that artemisinin is part of $A$. annua chemical system of defense against biotic and abiotic stress.

The treatment of 38-hr WD induced the highest foliar biomass accumulation and artemisinin content per plant, on a dry weight basis, compared to the control (figs. $1 \mathrm{C}$ and $1 D$ ). This increase in leaf biomass was unexpected because water deficit in general stops or reduces growth and biomass accumulation. The increased biomass was probably caused by the genotypic variation that occurs in seeds derived from cross pollinated plants of this hybrid. The parents used to obtain the hybrid 2/39X1V used in this study were not pure homozygous (as a pure hybrid parents would be) for biomass accumulation, but rather superior clones that were selected for those traits (Magalhães, 1996). However, artemisinin concentration in the plant is highly regulated by genetic factors with broad-sense heritability varying from 0.91 to 0.98 (Ferreira et al., 1995b) and narrow-sense heritability higher than 0.95 (Delabays, 1997). Thus, the increase in artemisinin content found in plants under the 38-hr WD ( $\Psi \mathrm{w}-1.39 \mathrm{MPa}$ ) was attributed to the treatment rather than to the genetic variability encountered in plants generated from seeds of this hybrid.

The dry biomass of stems and the leaf-to-stem ratio (Table 1) are important parameters influencing the industrial processing of $A$. annua. The stem has waxes that make difficult the isolation and purification of artemisinin. No significant differences were found for most treatments for dry stem biomass or for leaf-to-stem ratio. However, the 38hr WD treatment ( $\Psi \mathrm{w}-1.39 \mathrm{MPa}$ ) had a dry stem biomass higher than the control (Table 1), again attributed to genetical variability of the hybrid as discussed above.

Plants submitted to an 86-hr WD ( $\Psi \mathrm{w}-3.97 \mathrm{MPa})$ recuperated the turgor pressure ( $\Psi \mathrm{w}-1.8 \mathrm{MPa}) 64$ hours after they were rehydrated. Fourteen days after the plants were rehydrated, we noticed the death of the apical meristem of the main stem, resulting on the expanded growth of lateral stems due to the loss of apical dominance, but the plants survived. This tolerance of $A$. annua to such a water deficit indicates the plant is somewhat resilient to a short drought under the conditions used in this experiment. Our experience growing $A$. annua under field conditions is that, during short water shortages (10-14 days) the plants will show a loss in turgor pressure, the top of the plant will become droopy, but the plants regain turgor pressure after the first rain and survive, although with a decreased leaf biomass accumulation at the end of the season.

In conclusion, our results suggest that artemisinin could be part of $A$. annua chemical system of defense against waterdeficit. Also, the results suggest that the lack of irrigation (or absence of rain) one to two days before the $A$. annua crop is harvested can induce a moderate water deficit and lead to a significant increase in artemisinin without detriment to biomass accumulation. The lack of irrigation or rain will also be beneficial to hasten the drying process before industrial processing.

Acknowledgements: We are thankful to the Brazilian Council for Scientific and Technological Development (CNPq), Brazilian Ministry of Education (CAPES), and to the Bank of Brazil Foundation for their financial support.

\section{REFERENCES}

Allen PC, Lydon J, Danforth HD (1997) Effects of components of Artemisia annua on coccidia infections in chickens. Poultry Sci. 76: 1156-1163.

Baldi A, Dixit VK (2008) Yield enhancement strategies for artemisinin production by suspension cultures of Artemisia annua. Bioresour. Technol. 99: 4609-4614.

Baldwin IT, Halitschke R, Kessler A, Schittko U (2001) Merging molecular and ecological approaches in plant-insect interactions. Curr. Opin. Plant. Biol. 4: 351-358.

Balint GA (2001) Artemisinin and its derivatives. An important new class of antimalarial agents. Pharmacol. Ther. 90: 261-265.

Boyer JS (1995) Measuring the water status of plant and soils. Academic Press, San Diego.

Briskin DP (2000) Medicinal plants and Phytomedicines. Linking plant biochemistry and physiology to human health. Plant Physiol. 124: 507-514. 
Charles DI, Simon JE, Shock CC, Feibert EBG, Smith RM (1993) Effect of water stress and post-harvest handling on artemisinin content in the leaves of Artemisia annua L. In: Janick J, Simon JE (eds.) Proceedings of the second national symposium: New crops, exploration, research and commercialization. pp 640-643. John Wiley and Sons Inc., New York.

Chen FT, Zhang GH (1987) Studies on several physiological factors in artemisinin synthesis in Artemisia annua. Plant Physiol. Commun. 5: 26-30.

Danner MA, Sasso SAZ, Medeiros JGS, Marchese JA, I; Mazaro SM (2008) Indução de resistência à podridão-parda em pêssegos pelo uso de eliciadores em pós-colheita. Pesq. Agropec. Bras. 43: 793-799.

Delabays N, Simonnet X, Gaudin M (2001) The genetics of artemisinin content in Artemisia annua $\mathrm{L}$. and the breeding of high yielding cultivars. Curr. Med. Chem. 8: 1795-1801.

Dey PM, Harborne JB (1997) Plant Biochemistry. Academic Press, London.

Dixon RA, Paiva NL (1995) Stress-Induced phenylpropanoids metabolism. Plant Cell 7: 1085-1097.

Duhl TR, Helmig D, Guenther A (2007) Sesquiterpene emissions from vegetation: a review. Biogeosciences Discuss. 4: 3987-4023.

Efferth T (2005) Mechanistic perspectives for 1,2,4-trioxanes in anti-cancer therapy. Drug Resist. Update 8: 85-97.

Enserink M (2005) Source of new hope against malaria is in short supply. Science 307: 33-33

Ferreira JFS, Simon JE, Janick J (1995a) Developmental studies of Artemisia annua: flowering and artemisinin production under greenhouse and field conditions. Planta Med. 61: 167-170.

Ferreira JFS, Simon JE, Janick J (1995b) Relationship of artemisinin content of tissue-cultured, greenhouse-grown, and field-grown plants of Artemisia annua. Planta Med. 61: 351-355.

Ferreira JFS (2007) Nutrient deficiency in the production of artemisinin, dihydroartemisinic acid, and artemisinic acid in Artemisia annua L.. J. Agr. Food Chem. 55: 1686-1694.

Franz C (1983) Nutrient and water management for medicinal and aromatic plants. Acta Hort. 132: 203-215.

Galambosi B (1980) Results of cultivation of some wildflower medicinal plants in the "szilasmenti" cooperative. Acta Hort. 96: 343-352.

Ghershenzon J (1984) Changes in levels of plant secondary metabolites under water and nutrient stress. In: Timmermann BN, Steelin C, Loewus FA (eds) Recent advances in phytochemistry - phytochemical adaptations to stress. pp 273-220. Plenum Press, New York.

Hansen U, Seufert G (1999) Terpenoid emission from Citrus sinensis (L.) OSBECK under drought stress. Phys. Chem. Earth (B) 24: 681-687.

Harborne JB (1993) Introduction to Ecological Biochemistry. $3^{\text {rd }}$ ed. Academic Press, London.

Heath MC, Boller T (2002) Biotic interactions levels of complexity in plant interactions with herbivores, pathogens and mutualists. Curr. Opin. Plant Biol. 5: 277-278.

Herms DA, Mattson WJ (1992) The dilemma of plants: to grow or defend. Quart. Rev. Biol. 67: 283-235.

Jain DC, Mathur AK, Gupta MM, Singh AK, Verma RK, Gupta AP, Kumar S (1996) Isolation of high artemisinin-yielding clones of Artemisia annua. Phytochemistry 43: 993-901.

Kim JT, Park JY, Seo HS, Oh HG, Noh JW, Kim JH, Kim DY, Youn HJ (2002) In vitro antiprotozoal effects of artemisinin on Neospora caninum. Vet. Parasitol. 103: 53-63.

Klayman DL (1985) Qinghaosu (artemisinin): an antimalarial drug from China. Science 228: 1049-1055.

Knox JP, Dodge AD (1985) Singlet oxygen and plants. Phytochem. 24: 889896.
Kramer PJ, Boyer JS (1995) Water relations of plants and soils. Academic Press, San Diego.

Kuc J (1995) Phytoalexins, stress metabolism and disease resistance in plants. Annu. Rev. Phytopathol. 33: 275-297.

Kumar S, Gupta AK, Pal Y, Dwivedi SK (2003) In-vivo therapeutic efficacy trial with artemisinin derivative, Buparvaquone and Imidocarb Dipropionate against Babesia equi infection in donkeys. J. Vet. Med. Sci. 65: 1171-1177.

Book chapter references

Laird SA, Kate KT (2002) Biodiversity prospecting: the commercial use of genetic resources and best practice in benefit-sharing. In: Laird $S$ (ed) Biodiversity and traditional knowledge: equitable partnerships in practice, $p p$ 241-286. Earthscan Publications Ltd., London.

Larcher W (2003) Physiological Plant Ecology - Ecophysiology and stress physiology of functional groups. 4th ed. Springer-Verlag, Berlin.

Liu C, Wang Y, Xu X, Ouyang F, Ye H, Li G (1999) Improvement of artemisinin accumulation in hairy root cultures of Artemisia annua L. by fungal elicitor. Bioprocess Biosyst. Eng. 20: 161-164.

Liu Y, Wang H, Ye HC, Li GF (2005) Advances in the plant isoprenoid biosynthesis pathway and its metabolic engineering. J Int Biol 47: 769-82

Luo XD, Shen CC (1987) The Chemistry, pharmacology, and clinical applications of qinghaosu (artemisinin) and its derivatives. Med. Res. Ver. 7: $29-52$.

Maggi ME, Mangeaud A, et al. (2005) Laboratory evaluation of Artemisia annua L. extract and artemisinin activity against Epilachna paenulata and Spodoptera eridania. J. Chem. Ecol. 31: 1527-1536.

Magiero EC, Assmann JM, Marchese JA, Capelin D, Paladini MV, Trezzi MM (2009) Allelopathic effect of Artemisia annua L. on the germination and initial development of lettuce (Lactuca sativa L.) and wild poinsettia (Euphorbia heterophylla L.) seedlings. Braz. J. Med. Plant 11: 317-324.

Mann J (1987) Secondary metabolism. $2^{\text {nd }}$ ed. Clarendon Press, Oxford.

Marchese JA, Rehder VLG (2001) The influence of temperature in the production of artemisinin in Artemisia annua L.. Braz. J. Med. Plant 4: 8993.

Marchese JA, Rehder VLG, Sartoratto A (2001) A comparison of thin layer chromatography and high performance liquid chromatography for artemisinin analyses. Braz. J. Med. Plant 4: 81-87.

Marchese JA, Rehder VLG, Casiraghi V, Tedesco AC, Lira R (2002) Flowering in plants of Artemisia annua L. standed to diferent conditions of photoperiod and temperature. Acta Hort. 569: 275-280.

Marchese JA, Broetto F, Ming LC, Ducatti C, Rodella RA, Ventrella MC, Gomes GDR, Franceschi L (2005) Carbon isotope composition and leaf anatomy as a tool to characterize the photosynthetic mechanism of Artemisia annua L.. Braz. J. Plant Physiol. 17: 187-190.

Marchese JA, Figueira GM (2005) The use of pre and post-harvest technologies and good agricultural practices in the production of medicinal and aromatic plants. Braz. J. Med. Plant 7: 86-96.

Marchese JA, Ming LC, Franceschi L, Camochena RC, Gomes GDR, Paladini MV, Capelin D, Marchese CF (2009) Medicinal plants used by "Passo da Ilha" rural community in the city of Pato Branco, southern. Brazil. An. Acad. Bras. Ciênc. 8: 691-700.

Mishina YV, Khrishna S, Haynes RK, Meade JC (2007) Artemisinins inhibit Trypanosoma brucei rhodesiense in vitro growth. Antimicrob. Agents Chemother. 51: 1852-1854.

Munné-Bosch S, Falarab V, Paterakib I, López-Carbonella M, Celaa J, Kanellisb AK (2008) Physiological and molecular responses of the isoprenoid biosynthetic pathway in a drought-resistant Mediterranean shrub, Cistus creticus exposed to water deficit. J. Plant Physiol. 166: 136-145.

Oostendorp M, Kunz W, Dietrich B, Staub T (2001) Induced disease resistance in plants by chemicals. Eur. J. Plant Pathol. 107: 19-28. 
Palevitch D (1987) Recent advances in the cultivation of medicinal plants. Acta Hort. 208: 29-35.

Posner GH, Posner GH, Ploypradith P, Parker MH, O'Dowd H, Woo SH, Northrop J, Krasavin M, Dolan P, Kensler TW, Xie S, Shapiro TA (1999) Antimalarial, antiproliferative, and antitumor activities of artemisinin-derived, chemically robust, trioxane dimers. J. Med. Chem. 42: 4275-4280.

Putalun W, Luealon W, De-Eknamkul W, Tanaka H, Shoyama Y (2007) Improvement of artemisinin production by chitosan in hairy root cultures of Artemisia annua L.. Biotechnol. Lett. 29: 1143-1146.

Qian Z, Gong K, Zhang L, Lv J, Jing F, Wang Y, Guan S, Wang G, Tang, K. (2007) A simple and efficient procedure to enhance artemisinin content in Artemisia annua L. by seeding to salinity stress. African J. Biotechnol. 6: $1410-1413$

Qureshi MI, Israr M, Abdin MZ, Iqbal M. (2005) Responses of Artemisia annua $\mathrm{L}$. to lead and salt-induced oxidative stress. Environ. Exp. Bot. 53: 185-193.

Rodríguez-Concepción M, Boronat A (2002) Elucidation of the methylerythritol phosphate pathway for isoprenoid biosynthesis in bacteria and plastids. A metabolic milestone achieved through genomics. Plant Physiol. 130: 107989.

Singh A, Kaul VK, Mahajan VP, Singh A, Misra LN, Thakur RS, Husain A (1986) Introduction of Artemisia annua in India and isolation of artemisinin, a promising antimalarial drug. Indian J. Pharm. Sci. 48: 137-138.

Singh NP, Lai HC (2004) Artemisinin induces apoptosis in human cancer cells. Anticancer Res. 24: 2277-2280.

Staudt M, Chuine I (2005) Effects of an experimental increase of temperature and drought on isoprenoid emissions from Mediterranean ecosystems. Geophys. Res. Abstr. 7: 04606 (CEuropean Geosciences Union).
Turner NC (1981) Techniques and experimental approaches for the measurement of plant water status. Plant Soil 58: 339-66.

Utzinger J, Chollet J, Jiqing Y, Jinyan M, Tanner M, Shuhua X (2001) Effect of combined treatment with praziquantel and artemether on Schistosoma mansoni in experimentally infected animals. Acta Trop. 80: 9-18.

Wallaart, TE, Pras N, Beekman AC, Quax WJ (2000) Seasonal variation of artemisinin and its biosynthetic precursors in plants of Artemisia annua of different geographical origin: proof for the existence of chemotypes. Planta Med. 66: 57-62.

Wang JW, Xia ZH, Tan RX (2002) Elicitation on artemisinin biosynthesis in Artemisia annua hairy roots by the oligosaccharide extract from the endophytic Colletotrichum sp. B501. Acta Bot. Sinica 44: 1233-1238.

WHO - World Health Organization (2005) World malaria report 2005. WHO, Genebra.

Wittstock UTE, Ghershenzon J (2002) Constitutive plant toxins and their role in defense against herbivores and pathogens. Curr. Opin. Plant. Biol. 5: 1-8.

Xiao SH, Guo J, Chollet J, Wu JT, Tanner M, Utzinger U (2004) Effect of artemether on Schistosoma mansoni: dose-efficacy relationship, and changes in morphology and histopathology. Chinese J. Parasitol. Parasitic. Dis. 22: 148-153.

Yang DM, Liew FY (1993) Effects of qinghaosu (artemisinin) and its derivatives on experimental cutaneous leishmaniasis. Parasitol. 106: 7-11.

Yin L, Zhao C, Huang Y, Yang R, Zeng Q (2008) Abiotic stress-induced expression of artemisinin biosynthesis genes in Artemisia annua L.. Chin. J. Appl. Environ. Biol. 14: 1-5.

Zhao S, Zeng MY (1986) Application of precolumn reaction to highperformance liquid chromatography of qinghaosu in animal plasma. Anal. Chem. 58: 289-292. 